\title{
Early Chemistry in Oxford.1
}

\section{By Sir Edward Thorpe, C.B., F.R.S.}

$A \mathrm{~N}$ attempt is being made at Oxford to bring together such scattered information as exists concerning the early history of science in that University, and to commemorate the achievements of Tunstal, Richard of Wallingford, Merle, Mauduit, Rede, Aschenden-forgotten worthies of a medieval time--and of Digges, Recorde, Dwight, Lower, Mayow, and others of a later period. As regards physical science, it is intended to illustrate its development by a sort of catalogue raisonné of scientific instruments, mainly from the collections in the various colleges and University departments which are known to be rich in specimens of the best work of the craftsmen of the seventeenth and eighteenth centuries.

The present booklet - the first instalment of the projected series-deals with the history of chemistry at Oxford down to the time of Daubeny. It traces the beginnings from Roger Bacon (1 $214-92$ ), who may be said to have well and truly laid its foundations as a science by his insistence on the appeal to experiment. His dictum, Sine experientia nihil sufficienter sciri potest, now over the entrance to an Oxford laboratory, is significant not only of his breach with scholasticism, but also of his clear recognition of the path that science must follow. Mr. Gunther deals only in very general terms with the influence of Bacon-more with his teaching and the essential nature of his philosophy than with his actual achievements. He sees his limitations in the dominance of the Greek philosophy, and in his inability to act, through force of circumstances, upon his own principles. Considering that Bacon's name is associated with Oxford traditions, and that the book is primarily intended for Oxford students, to whom, indeed, it is dedicated, more space might well have been allotted to one who was "at once the earliest and among the greatest of our [Oxford] teachers."

The early association of chemistry with medicine was, of course, felt in Oxford, as elsewhere. The Spiceria of medieval Oxford were to be found in the High Street, near the site of the present front of Brasenose College. Their shops, which did not escape being occasionally "ragged," dealt originally in spices, seeds, and roots, and only gradually developed into apothecaries. One of the earliest was that of John le Spicer, whose shop, in $\mathrm{r}_{332}$, was in All Saints parish. Mr. Gunther furnishes a plan showing the apothecaries' quarters in Oxford, and he gives illustrations of their receptacles for drugs from the series in the Ashmolean Museum.

From the times of Roger Bacon and the early spicers to the middle of the seventeenth century is a big jump. But Oxford contributed nothing to chemical science during the intervening period. The study of natural phenomena was foreign to the scholastic learning of the time. As Mr. Gunther points out, "the long list of Waynflete

1 "Eatly Science in Oxford." Part i., "Chemistry." By R. T. Gunther Pp. vitgr. (Oxford: The Oxford Science Laboratories, x920.) $6 s$. NO. 2679 , VOL. IO7] readers of Natural Philosophy, none of whom left any original work, shows how barren discourses on this subject must be, when they are founded on Aristotle rather than on Nature." There were, however, alchemists during this period in Oxford, among them the Rosicrucian Fludd, of St. John's, in I591, and Simon Forman and John Thornborough (1602), of Magdalen. Mention should also be made of John French (1616-57), who wrote treatises on distillation, "partly taken out of the most select Chymicall Authors of several Languages, and partly out of the Author's manuall experience." But the real awakening in Oxford occurred during the troubles of the Civil War, when Wilkins, Ward, Bathurst, Petty, and Willis met weekly, first in an apothecary's house for "the convenience of inspecting drugs," next at the lodgings of Dr. Wilkins, warden of Wadham, and afterwards at the lodgings of Mr. Robert Boyle. The last-named had settled, in 1654 , in Crosse's rooms in the High Street, having recently ieft Ireland, "a barbarous country," he says, "where chemical spirits were so misunderstood, and chemical instruments so unprocurable, that it was hard to have any Hermetic thoughts in it."

This association of the progenitors of the Royal Society with Oxford is an incident of which the University is justly proud, and $\mathrm{Mr}$. Gunther treats of it in some detail. Boyle, who was of a tender constitution, was devotedly looked after by his sister, Lady Ranelagh, who came up to Oxford to settle him in his lodgings. While there, we learr. from a letter which Mr. Gunther prints, she was not wholly satisfied, as she thinks the position of the doors with respect to the fireplace, even in the warmest room, will occasion draughts, "the inconvenience" of which "may be helped . . . by a folding screen." Boyle, however, was sufficiently comfortable to remain there for fourteen years, when he removed to London to his new laboratory at the back of Lady Ranelagh's house in Pall Mall. Crosse's house in Oxford was pulled down in I809; it was where the Shelley memorial now stands. Mr. Gunther gives a reproduction of an old print showing it and its relation to University College and other buildings in the High Street (Fig. I).

Oxford owes to Boyle its first regular teacher of practical chemistry-Peter Sthael, of Strassburg, "a Lutheran, a great hater of women, and a very useful man," who had been engaged by Boyle as one of his assistants. He began his courses in 1659. Among his pupils was John Locke, of Christ Church, "a man of turbulent spirit, clamorous and never contented. The club [class] wrote and took notes from the mouth of their master, who sat at the upper end of a table; but the said J. Lock scorned to do it; so that while every man besides of the club were writing, he would be prating and troublesome." That the fingers of the troublesome J. Locke did actually itch to be at chemical experimenting is shown by 
his subsequent action, for an account of which we must refer to the book itself.

Oxford is associated with the discovery of the art of salt-glazing stoneware, due to John Dwight (166r), of Christ Church. John Ludwell, fellow of Wadham, about 1670 experimented on the manufacture of glass, which he surmised was a kind of solution.

With the removal of the members of the "philosophicall Clubbe" to London, the pursuit of experimental inquiry languished and almost died out. The chief glory of Oxford in the years immediately following the $\mathrm{Re}$ storation was John Mayow, fellow of All Souls, who left the University in 1675 and settled at Bath as a physician. He died four years later at the age of thirty-six. On his epochmaking work-his "Tractatus de Respiratione," in which he recognised the real nature of atmospheric air, and of the function of one of its constituents in supporting combustion and respiration-as also on his subsequent treatises in which he further elaborated his practical discovery of oxygen, there is no need to enlarge. Mr. Gunther styles him "the greatest chemist whom Oxford has ever produced.'

The first University chemical laboratory was established by Elias Ashmole, whose original scheme for the foundation of a scientific institution comprised an "elaboratory," as well as a repository for his "raree show" of archæological curios. The Officina Chymica was housed in the cellar of the building, which was erected in $x 683$, and placed under the charge of Dr. Plot. "Certaine scholars" of the Philosophical Society of Oxford thereupon "went a course of chimistrie" and "had meetings in the large room over the elaboratory Every Friday in the afternoone to talke of Chymicall matters," "their discourses" being "registered down" by Dr. Plot. Plot resigned his office in $I 689$, and was succeeded by Mr. Edward Hannes, of Christ Church. In ryo4 Hannes was followed by $\mathrm{Dr}$. John . Freind, also of Christ Church, who is described as "well-skill'd in Speculative and Practical Chymistry," and "the first who applied the Newtonian philosophy to chemistry." He was assisted by Richard Frewin, of the same college, and Camden professor of ancient history, who seems to have had charge of the Ashmolean Laboratory. The latter, according to Uffenbach, the traveller, who visited it in I710, "does not trouble much about it, and the operator, Mr. White (said to be a good-fornothing man) still less." "Not only are the finest instruments, tiles, and such like, almost all broken to pieces, but the whole place is filthy." Mr. Gunther is of opinion that at least one good thing emerged from the furnaces of the Ashmoleannamely, Dr. John Wall, a fellow of Merton, who probably gained there the knowledge of operative chemistry which enabled him to study the manufacture of porcelain, and ultimately to found the famous china factory of Worcester.

Another Dr. Wall, known as Martin Wall (1747-1824), a fellow of New College, in $178 \mathrm{r}$ became public reader of chemistry. He, accord-

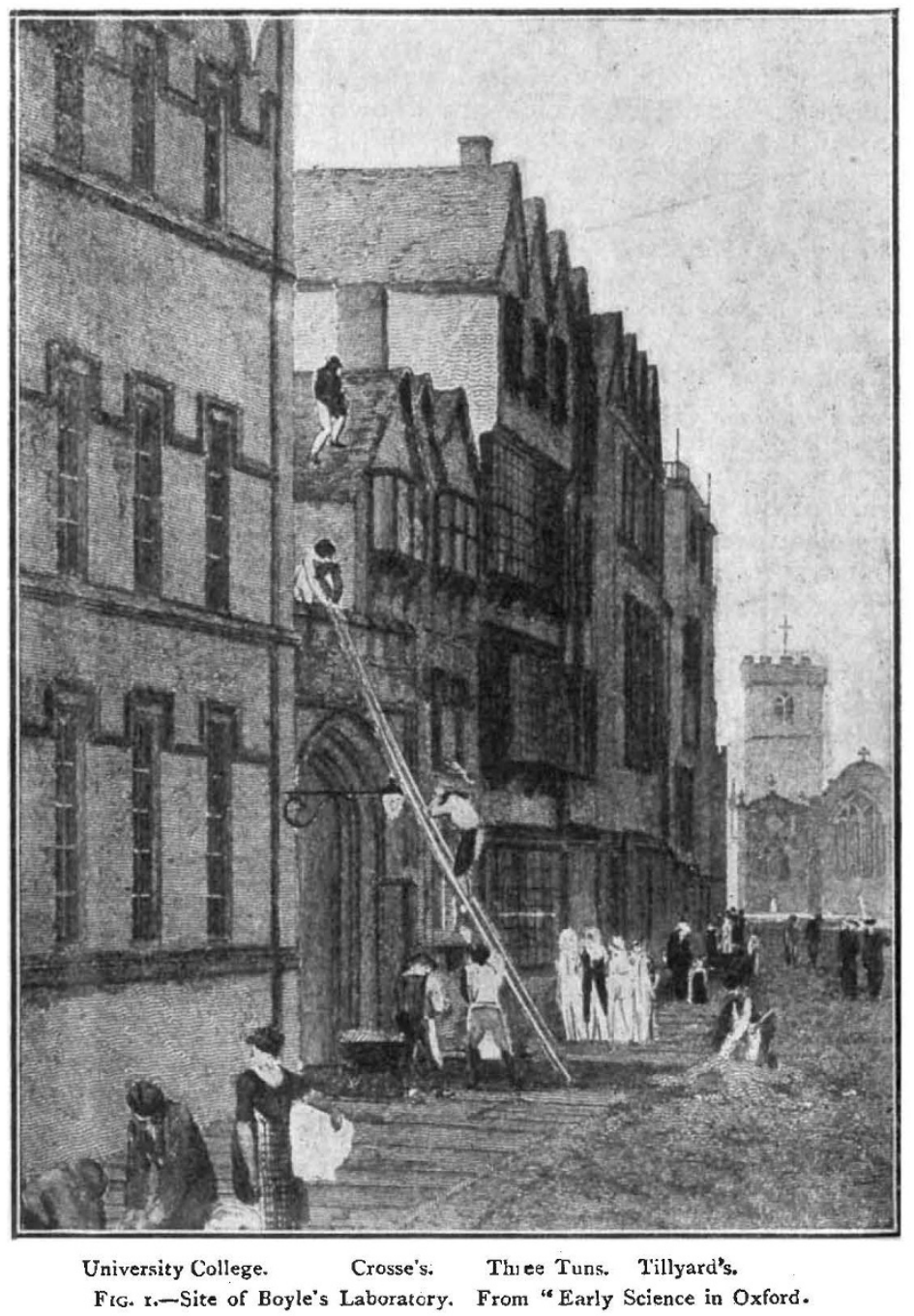

ing to our author, taught that chemistry "is an immediate revelation from Heaven to Adam, and had its name from Cham, the progenitor of the Egyptians." "Chymistry" is not only "a piece of knowledge not mis-becoming a gentleman, but it promises to afford a firm and elegant basis for a compleat skill in Natural Philosophy-and certainly will enable any divine in Europe to describe with confidence. the operation by which Moses might have reduced the golden calf to powderto the confusion of Voltaire and all his disciples." No. 2679 , VOL. IO7] 
The early memoirs of the Manchester Philosophical Society contain several papers by Wall, brief notes of whose lectures are preserved in MS. in the Radcliffe library and in private letters of the time; some of the latter are printed by $\mathrm{Mr}$. Gunther. Wall is described as a "learned, ingenious, and pleasing gentleman," who once had the honour of drinking tea with Dr. Samuel Johnson.

A contemporary of Wall's, James Higginbotham, of Magdalen Hall, afterwards James Price, of Guildford, was the last of the English alchemists, and killed himself after the exposure, by a committee of the Royal Society, of his pretensions to transmute mercury into gold.

From the closing years of the eighteenth century to the time of the foundation of the Aldrichian professorship, Oxford readerships in chemistry were held in succession by Dr. Thomas Beddoes (1788-93), best known as the founder of the "Pneumatic Institution" at Clifton, and the discoverer of Humphry Davy; and Dr. Robert Bourne, a fellow of Worcester, and an eminent medical man of his time. Indeed, practically all the readerships were held by medical men, and their teaching was largely directed to the needs of medicine.

In 1803 Dr. G. Aldrich endowed a professorship of chemistry. The first occupant of the chair was John Kidd, who held it from 1803 to 1822 . $\mathrm{He}$ is the author of two papers in the Phil. Trans., one on "Naphthaline, a peculiar substance . . . produced during the decomposition of coal-tar"; the other on "The natural production of Saltpetre in the walls of subterraneous buildings," the saltpetre having been scraped from "the hoary walls" of the basement of the Ashmolean Museum in which Dr. Kidd and his family resided.
Dr. Kidd was succeeded by Dr. Charles G. B. Daubeny, a professor of botany to chemists, and a professor of chemistry to botanists, who held the chair for thirty-two years, when his "increasing duties at the Botanic Garden compelled him to resign his Chemical Professorship." The cellar at. the Ashmolean, although, as Daubeny said, "notoriously unworthy of a great University, being dark, inconvenient, and confined," was afterwards occupied by the late Prof. Story-Maskelyne, who gave instruction there in chemical analysis. An incident connected with his tenancy of this basement is related by $\mathrm{Mr}$. Gunther in a footnote with which this notice of a most interesting account of Oxford's relations to chemistry must conclude :-

Some workmen were employed to make some alterations to a wall when one of them drove his pick through into a small room that had evidently not seen the light of day for generations. They enlarged the aperture, and, on entering, found some bottles that appeared to them of extreme antiquity. Very naturally they tasted the contents and speculated on the possible origin of the long forgotten hoard. When eventually the discovery was reported to Maskelyne, then at the mineralogical department at the British Museum, he exclaimed, "They have broken into my cellar, the stupid idiots. If they had only looked at the other side they would have seen my new oak door." But what probably rankled in his mind was the thought that his own gin had impaired their clear vision.

Mr. Gunther's surmise cannot, however, be well founded, as the gin was reached only after the wall had been broken through. It was presumably the same wine cellar that Dr. Daubeny had vainly petitioned Convocation to improve for him.

\section{Pons-Winnecke's Comet and its Meteor Shower.}

\section{By W. F. Denning.}

A NEW comet was discovered by Jean Louis A Pons at Marseilles in June, 1819, and it was observed during five weeks. From the observations obtained, Encke computed that the comet was revolving in an elliptical orbit, with a period of $205^{2}$ days, or 5.618 years. Nothing more was, however, seen of the object until nearly forty years afterwards, when Winnecke re-discovered it, and also re-determined its period of revolution. It has since been observed in 1869 , 1875, 1886, 1892, 1898, 1909, and 1915. During the last fifty years the planet Jupiter has somewhat disturbed the orbit of the comet, for the two objects made several near approaches. Two periods of the comet are nearly equivalent to one period of Jupiter, hence at alternate visits of the former to aphelion, as in about $1872,1883,1895$, and 1907 , the perturbations were considerable. These had the effect of lengthening the comet's period and bringing that section of its course which is nearest to the sun almost into conjunction with the earth's path at the end of June.

On June 28 , I9ı 6 , a meteoric shower of strikNo. 2679 , VOr. IO7] ing and abundant character was observed by the present writer at Bristol. It was first seen there at 10.25 p.m., and half an hour later it was also observed from Bournemouth and Birmingham. The sky was not very favourable, but at Bristol sixty-nine meteors were observed in about two hours, including twenty of the first magnitude, and the radiant point appeared to be diffused over the region of $\eta$ Ursæ Majoris, $\theta$ Boötis, and a little east. This position corresponded approximately with the radiant point computed for Pons-Winnecke's comet, and the date was also correct, so that an intimate association (or identity) of the two phenomena was suggested (see Monthly Notices of the Royal Astronomical Society for 19r6, vol. 1xxvi., p. 742). The meteoric shower named is likely to be repeated, and on a more brilliant and abundant scale, on about June 27 next, for the comet will be very much nearer to the earth than it was in June, 19r6. On that occasion the meteors were seen about ten months after the comet's nucleus had passed through perihelion, so that the stream of 